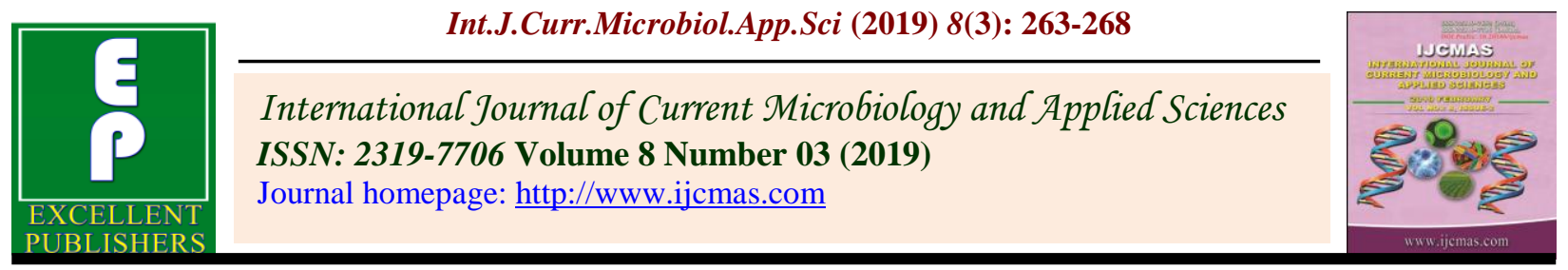

Original Research Article

https://doi.org/10.20546/ijcmas.2019.803.033

\title{
Training Needs of Dairy farm Women Regarding Scientific Animal Husbandry Practices in Rajkot District of Gujarat
}

\author{
V.S. Prajapati*, P.S. Sharma, S.V. Undhad, N.B. Jadav and A.R. Parmar
}

Krishi Vigyan Kendra, Junagadh Agricultural University, Pipalia (Dhoraji), Rajkot-II, India

*Corresponding author

\section{A B S T R A C T}

Keywords

Dairy farm women,

Animal husbandry

practices, Training,

Livestock, Breeding

Article Info

Accepted:

04 February 2019

Available Online:

10 March 2019
The present study was conducted by keeping a concept in mind that dairy development is not feasible unless dairy farm women are trained in scientific dairy farming. The present study was conducted in KVK operational area of Rajkot district with 80 dairying farm women purposively selected who were intensively carried out agriculture and dairying activities. The study inferred that overall distribution of dairy farmwomen according to training need, 56.25 per cent had medium training need followed by high training need. Dairy farm women had most needed training in aspect of animal nutrition practices $(\mathrm{WMS}=2.38$ ) and animal breeding practices (WMS=2.26). Hence, realistic and effective planning for education and training need to be done to enhance the skill and adaptation of better scientific practices for livestock farmers in an appropriate way. Simultaneously it can also be suggested that the livestock owners should be acquainted with appropriate animal husbandry practices scientifically and also female teacher trainer was most suitable for effective training practices.

\section{Introduction}

The animal husbandry sector plays an important role in GDP of Gujarat state, which is to the tune of nearly about $5.0 \%$. Dairy is an essential component of the district. There is a long tradition of rearing dairy animals by the farmers in the district. Large numbers of landless families are also engaged in dairy animal rearing and running their household expenses successfully. There exists wide gap between the average yield and attainable yield and/or potential yield which offers a big scope for improvement in productivity. Operational training provides a systematic improvement of knowledge and skills which in turn helps the trainees to function effectively and efficiently. So, effective training requires a clear picture of how the trainees will need to use information and technology after training in place of such local practices what they have adopted before in their situation (Lynton et al., 1990). It is a common observation that dairy farm women are fully engaged in care and management of dairy animals. It is thus, imperative that dairy development is not feasible unless dairy farm women are trained in scientific dairy farming. Now a day's training institutes (KVK, State A.H. department, Gujarat) in the district have started training programme to the dairy farm women. However, in the absence of sound 
research findings, very little experiences are available with the organizer and trainers to this programme need based and thereby more scientific and effective. Adoption of improved animal husbandry practices like breeding, feeding, management, health care etc., are necessary to improve the productivity of dairy cattle and thereby making dairy farming a more profitable enterprise. Through training, the dairy farm women not only learn about the improved animal husbandry practices but also able to make their enterprise a successful one. For making training effective, it should be based on their felt needs. The training programme, which is not need based have little impact on bringing desired change in the clientele system.

\section{Materials and Methods}

The present study was conducted purposively in the jurisdiction of the Krishi Vigyan Kendra, JAU, Pipalia. Two talukas were selected randomly for conducting the present investigation. Eight villages were further purposively selected from two talukas where dairy husbandry practiced. Initially, an exhaustive list of livestock owners was prepared from the all eight selected villages. Then from each village a total sample of 10 farmwomen was selected who were engaged in dairy farming. Accordingly, 80 farm women will be selected purposively from each of the eight villages. An interview schedule will be prepared to collect the required information as per the objective of the study. Data was collected by personal interview method. The collected data was further quantified, categorized and tabulated. Analysis was carried out by using frequencies and percentage (Table 1).

\section{Measurement of variables}

To find out the socio-economic characteristics, frequency and percentage were worked out and discussed further. To assess dairy farm women training need about animal husbandry practices, ten-item statements were presented and assessment based on a three point Likert-type rating scale of most needed coded 3, somewhat needed coded 2 and not needed coded 1, mean scores was calculated. A unit score was calculated and total score obtained by individual respondents for all the statement was calculated. With the help of mean and standard deviation the respondents were categorized as low, medium and high category. To find out the subject wise training need of dairy farm women about animal husbandry practices, weighted mean score was find out and ranks were given according to WMS.

\section{Results and Discussion}

The data presented in Table 2 indicated the personal and socio economic characteristics of dairying farm women and revealed that majority (55.00 per cent) of the respondents were in the middle age group followed by 23.75 and 21.25 per cent of the respondents belonged to the young and old age group respectively. The probable reason that could be attributed to these findings may be that this is the major group who can physically look after their animals. While in case of education that is presented in Table 2 majority 40.00 per cent of the respondent were educated up to secondary level whereas, 22.50 per cent of the respondents were educated up to primary level followed by 21.25 per cent respondents were educated up to high secondary level, 8.75 per cent respondents were graduate and 7.50 per cent respondents were illiterate.

The data presented further revealed that higher percentage (46.25 per cent) dairy farm women was found to have medium size land holding, while 33.75 percent dairy farm women were found to have small size of land 
holding, whereas 12.50 percent dairy farm women had marginal size of land holding, and only 7.50 per cent dairy farm women had large size of land holding. This might be due to that dairy farm women had main occupation is rearing the animals, and in order to maintain their animals, they may be cultivating the land. The perusal of data in Table further indicated that 40.00 per cent of dairy farm women belonged to very high annual income followed by 27.50 per cent of dairy farm women had high annual income. Whereas 17.50 and 11.25 per cent dairy farm women belonged to medium and low annual income group respectively. only 3.75 per cent of dairy farm women had low annual income i.e. up to Rs. 100000.

The data of dairy farm women distribution according to their dairying experience depicted further and found that majority 66.25 per cent of dairy farm women had medium experience as dairying followed by 22.50 per cent respondents had high dairying experience. Only 11.25 per cent farm women possessed low dairying experience. The data further revealed that 67.50 per cent dairy farm women fell in medium social participation category followed by 21.25 per cent dairy farm women fell in low social participation category and 11.25 per cent dairy farm women belonged to high social participation group. This might be due to that women are less active in social activities. In case of herd size, 72.50 per cent dairy farm women had a medium herd size (i.e. 3-7 animal) while 17.50 per cent dairy farm women had more than 7 animals. Only 10.00 per cent dairy farm women had less than 2 animals. Milk yield production data presented in table in which 42.50 per cent dairy farm women had medium milk yield followed by 41.25 per cent dairy farm women had low milk yield. While 16.25 per cent dairy farm women had high milk yield.

\section{Distribution of the dairy farm women according to their training need}

The collected data of dairy farm women training need about animal husbandry practices presented in Table 2, it is quite clear from the data that 56.25 per cent of dairy farm women had medium training need whereas, 27.50 per cent had high followed by 16.25 per cent had low training need about animal husbandry practices. This might be due to fact that dairy farm women had medium social participation and medium dairying experience.

The data in Table 3 represented about areawise training need of dairy farm women about animal husbandry practices viz; breeding, feeding, health care, management of the Mastitis. It was assessed by personal interview method using structured interview schedule. The results were calculated as weighted score and accordingly ranks were given for each of the thrust area of animal husbandry practices identified for the training. Among ten subject, highest to lowest needed training were: Animal nutrition practices (WMS=2.38) ranked first, Animal breeding practices (WMS $=2.26)$ ranked second whose findings are in consonance with Vahora et al., (2015) who also reported that adequate and proper breeding practices helps into maintain optimum production of dairy animal, Animal health care practices (WMS=2.21) ranked third, Feeding practices in milking and dry animal (WMS=2.18) ranked fourth, Artificial insemination and heat detection of animal (WMS=2.05) ranked fifth, Vaccination and deworming in the animal (WMS=2.03) ranked sixth and the same results are in par with the findings of Raju et al., (1999), Das et al., (2002) and Durga et al., (2009), Take care of animal new born calves (WMS=1.94) ranked seventh, Care and Management of the mastitis in milking animal (WMS=1.93) ranked eighth, Animal husbandry practices in 
the agricultural operation $(\mathrm{WMS}=1.85)$ ranked ninth and Importance of record

keeping in the dairy business (WMS=1.76) ranked tenth.

Table.1 Distribution of respondents according to their characteristics $N^{*} 80$

\begin{tabular}{|c|c|c|c|}
\hline Sr. & Characteristics & Frequency & Percentage \\
\hline \multirow[t]{4}{*}{1} & Age & & \\
\hline & Young age (Up to 35 years) & 19 & 23.75 \\
\hline & Middle age ( 36 to 55 years) & 44 & 55.00 \\
\hline & Old age (above 55 years) & 17 & 21.25 \\
\hline \multirow[t]{6}{*}{2} & Education & & \\
\hline & Illiterate & 6 & 7.50 \\
\hline & Primary ( 1 to $7^{\text {th }}$ std.) & 18 & 22.50 \\
\hline & Secondary ( 8 to $10^{\text {th }}$ std.) & 32 & 40.00 \\
\hline & Higher Secondary ( $11^{\text {th }}$ to $12^{\text {th }}$ std.) & 17 & 21.25 \\
\hline & Graduate (above $12^{\text {th }}$ std.) & 7 & 8.75 \\
\hline \multirow[t]{5}{*}{3} & Size of land holding & & \\
\hline & Marginal (up to $1 \mathrm{ha}$ ) & 10 & 12.50 \\
\hline & Small (1.01 to 2 ha) & 27 & 33.75 \\
\hline & Medium (2.01 to 4 ha) & 37 & 46.25 \\
\hline & Large (Above 4 ha) & 6 & 7.50 \\
\hline \multirow[t]{6}{*}{4} & Annual income & & \\
\hline & Very low annual income (up to $\square 100000$ ) & 3 & 3.75 \\
\hline & Low annual income ( $\square 100000$ to 150000$)$ & 9 & 11.25 \\
\hline & Medium annual income ( $\square 150000$ to 200000 ) & 14 & 17.50 \\
\hline & High annual income ( $\square 200000$ to 250000 ) & 22 & 27.50 \\
\hline & Very high annual income (above $\square 2,50,000$ ) & 32 & 40.00 \\
\hline \multirow[t]{4}{*}{5} & Dairying experience & & \\
\hline & Low experience (below 4.72) & 9 & 11.25 \\
\hline & Medium experience (between 4.72 to 12.36 ) & 53 & 66.25 \\
\hline & High experience (more then 12.36) & 18 & 22.50 \\
\hline \multirow[t]{4}{*}{6} & Social participation & & \\
\hline & Low social participation (below 1.01) & 17 & 21.25 \\
\hline & Medium social participation (1.01 to 3.24 ) & 54 & 67.50 \\
\hline & High social participation (above 3.24 ) & 9 & 11.25 \\
\hline \multirow[t]{4}{*}{8} & Herd size & & \\
\hline & Low herd size (Up to 2 animal) & 8 & 10.00 \\
\hline & Medium herd size (3-7 animal) & 58 & 72.50 \\
\hline & High herd size (above 7 animal) & 14 & 17.50 \\
\hline \multirow[t]{4}{*}{9} & Milk Yield & & \\
\hline & Low milk production (up to 3300 lit.) & 33 & 41.25 \\
\hline & Medium milk production (3301 to 9600 lit.) & 34 & 42.50 \\
\hline & High milk production (above 9600 lit.) & 13 & 16.25 \\
\hline
\end{tabular}


Table.2 Distribution of the dairy farm women according to their training need

\begin{tabular}{|c|c|c|c|}
\hline $\begin{array}{c}\text { Sr. } \\
\text { No. }\end{array}$ & Category & Frequency & Percentage \\
\hline $\mathbf{1}$ & Low training need (Below 14.83 score) & 13 & 16.25 \\
\cline { 2 - 4 } 2 & Medium training need (14.83 to 24.60 score) & 45 & 56.25 \\
\hline \multirow{2}{*}{$\mathbf{3}$} & High training need (Above 24.60 score) & 22 & 27.50 \\
\cline { 2 - 4 } & & & 100 \\
\hline
\end{tabular}

Table.3 Distribution of respondents according to subject-wise training need

\begin{tabular}{|c|c|c|c|c|c|c|}
\hline $\begin{array}{l}\text { Sr. } \\
\text { No. }\end{array}$ & Subject & $\begin{array}{c}\text { Most } \\
\text { needed }\end{array}$ & $\begin{array}{l}\text { Somewhat } \\
\text { needed }\end{array}$ & $\begin{array}{c}\text { Not } \\
\text { needed }\end{array}$ & WMS & Rank \\
\hline 1 & Animal nutrition practices & 32 & 46 & 2 & 2.38 & I \\
\hline 2 & Animal breeding practices & 28 & 45 & 7 & 2.26 & II \\
\hline 3 & Animal health care practices & 25 & 47 & 8 & 2.21 & III \\
\hline 4 & $\begin{array}{l}\text { Feeding practices in milking and dry } \\
\text { animal }\end{array}$ & 22 & 50 & 8 & 2.18 & IV \\
\hline 5 & $\begin{array}{l}\text { Artificial insemination and heat detection } \\
\text { of animal }\end{array}$ & 14 & 56 & 10 & 2.05 & V \\
\hline 6 & $\begin{array}{l}\text { Vaccination and deworming in the } \\
\text { animal }\end{array}$ & 15 & 52 & 13 & 2.03 & VI \\
\hline 7 & Take care of animal new born calves & 17 & 41 & 22 & 1.94 & VII \\
\hline 8 & $\begin{array}{l}\text { Care and Management of the mastitis in } \\
\text { milking animal }\end{array}$ & 18 & 38 & 24 & 1.93 & VIII \\
\hline 9 & $\begin{array}{l}\text { Animal husbandry practices in the } \\
\text { agricultural operation }\end{array}$ & 15 & 38 & 27 & 1.85 & IX \\
\hline 10 & $\begin{array}{l}\text { Importance of record keeping in the } \\
\text { dairy business }\end{array}$ & 13 & 35 & 32 & 1.76 & $X$ \\
\hline
\end{tabular}

It is concluded that the aim of the study is to find out the ways where better training skills are needed to bring more efficient performance in the livestock optimum production. Farm women need training in many areas of animal husbandry activities. Adequate training in areas of animal nutrition practices and animal breeding practices is needed. There is a great need for conducting more number of needs based and well-tailored training programme suited to livestock farmwomen. It would definitely in turn help them to have more extension agency contacts especially female extension trainer. Training need was irrespective with their size of land holding, annual income and social participation. To organize more effective training must be subject-wise at KVK before monsoon and before cropping season. The one-day training duration was most appropriate and four times in a year. Thus the livestock owners should be acquainted with 
improved management practices through appropriated training programmes to obtain more output from their livestock.

\section{References}

Das, L. and Mishra, S. K. (2002).Training needs of tribal women in farm and home activities. Agricultural Ext. Rev, 14(2): 3-6.

Durga, R. V. and Subhadra, M. R. (2009). Training needs of farm women in dairy farming. Veterinary World, 2(6):
221-223.

Lynton, R. P. and Pareek, U. (1990). Training for Development, New Delhi: Vistaar Publications.

Raju, L. D., Nataraju, M. S. and Niranjan, M. (1990). Women in animal production an ex-post facto analysis. Agricultural Ext. Rev, 11(3): 3-8.

Vahora, S. G., Thorat, G. N. and Ramjiyani, D. (2015). Training Needs Perceived by Dairy farmers regarding Dairy and Animal Husbandry Practices. Guj. J. Ext. Edu, 26(2): 244-250.

\section{How to cite this article:}

Prajapati, V.S., P.S. Sharma, S.V. Undhad, N.B. Jadav and Parmar, A.R. 2019. Training Needs of Dairy farm Women Regarding Scientific Animal Husbandry Practices in Rajkot District of Gujarat. Int.J.Curr.Microbiol.App.Sci. 8(03): 263-268.

doi: https://doi.org/10.20546/ijcmas.2019.803.033 